\title{
Bosnia and Herzegovina Terra Incognita in the Academia of Europe
}

\author{
Marijana Secibovic ${ }^{1, *}$ Refik Secibovic ${ }^{1, a}$ Alaudina Boskailo ${ }^{1, b}$
}

\author{
${ }^{1}$ College of Tourism and Management, Private Higher Education Institution, Bosnia and Herzegovina \\ aE-mail: refik@bos.rs \\ bE-mail: alaudina.vstim@gmail.com \\ *Corresponding author. E-mail: marijanasecibovic@yahoo.com
}

\begin{abstract}
Bosnia and Herzegovina is a "terra incognita" for the European Higher Education Area (EHEA), but it is especially unknown to European agencies, organizations and networks. Regardless of the signing of the Bologna Declaration in 2003, most standards and documents have never been fully implemented or it is more suitable to say that they were never implemented at all. The lack of a ministry at the state level (in addition there are $\mathbf{1 3}$ lower ministries of education at different levels, from cantons to entities) created a problem because there are no strategic documents or a clear educational policy that would give direction to development. Ethnic and political authorities are not very interested in the modernization of universities and colleges, and they could even say that higher education institutions are in some form of scientific and teaching "hibernation". Failure in this area has brought academic staff and students into a state of struggle for survival, which is why most of the employees and students are thinking of leaving the country. In addition, the "university mafia" was formed, which is now controlled by most of the public and private universities. Quality education deals mainly with only a few institutions that have direct links with similar universities abroad. The higher education curriculum is at its peak, the fetal thought is completely suppressed. Solutions can only be carried out with the help of European universities and European organizations and agencies, but in a different way. The article proposes solutions relating to the creation of a unified system for the development of science and higher education.
\end{abstract}

Keywords: Bosnia and Herzegovina, higher education, understanding, echo chambers, teaching hibernation

\section{INTRODUCTION}

Bosnia and Herzegovina is a European country just a few hundred kilometers away from one of Vienna's leading European centers, or better yet, a country bordering the European Union. However, in the academic world, it is thousands of miles away, or rather decades away from the European community or from research centers where modern approaches to science and higher education are taking place.

Its complicated system of education has made the nowadays lives of scientists and professors so covered by a veil of fictitious laws and decisions that it is difficult to explain to scholars and reform actors within the European Higher Education and Science Area. Therefore, they simply cannot perceive the gravity and vulnerability when it comes to the educational and research work of these people in Bosnia and Herzegovina.
In case of Bosnia and Herzegovina this does not apply in other areas, such as arts (especially cinema whose directors and films received some of the most significant awards) or sports (specifically team sports - football and basketball) where citizens of this country belong to the European top, but are as well recognized in the rest of the world.

That is why it is often emphasized that Bosnia and Herzegovina is "terra incognita" for the European Research and Education Area.

Why is that the case?

In order to begin to explain the problems of scholars and professors at all, some facts must be presented that strongly burden the academic scene in $\mathrm{BiH}$ :

- The constitution of science and education in Bosnia and Herzegovina is very complex and burdened with legal, political, national and traditional barriers and restrictions; 
- The Dayton Constitution (or the Peace Agreement, which is in fact the constitution of the state) has precisely limited and hindered the development and modernization of science and higher education in the country;

- The fragmentation of institutions and their high dependency, whose tradition lacked in socialism as well, made it impossible to create conditions for the assembly of scientific teams at the national level, and their appropriate representation outside Bosnia and Herzegovina, and their ability to achieve European or global cooperation;

- War conflicts and aggression (from 1992 to 1995) severely impoverished the scientific and educational base, which, due to its isolation, is seriously lagging behind in terms of needs and environment;

- The higher education and science management system does not have the support of professional centers or institutes, which deal with the problems of higher education institutions development, quality or outcomes of education and scientific research.

This complexity of Dayton Bosnia and Herzegovina is reflected in a large number of institutions and administrative organizations, which unfortunately employ few professionals in this field:

"The constitution defines Bosnia and Herzegovina as an independent state composed of two entities: the Federation of Bosnia and Herzegovina (FB\&H) and Republic of Srpska (RS). Brcko District (BD) was founded as a separate administrative unit under the sovereignty of Bosnia and Herzegovina. The Federation of $\mathrm{B} \& \mathrm{H}$ consists of ten cantons. The executive administration of the country consists of 14 governments - one at the national, two at the entity level, ten cantonal and one of the Brcko District. This also means that there are fourteen different institutions dealing with education in the country: The Ministry of Civil Affairs of B\&H at the national level, two entity ministries of education (Federal Ministry of Education and Science and the Ministry of Education and Culture of RS), 10 cantonal ministries of education and Department for Education in the Brcko District Government. The Ministry of Civil Affairs of Bosnia and Herzegovina, in consultation with other relevant ministries, is responsible for general educational policy and international co-operation in the field of higher education at the national level, including the promotion of links between $\mathrm{B} \& \mathrm{H}$ and foreign higher education institutions and the student and staff mobility in the field of higher education in Europe and at the international level. In $\mathrm{FB} \& \mathrm{H}$, the main function of the Federal Ministry of Education and Science is to coordinate the activities of the ten cantonal ministries of education, while in the Republika Srpska the Ministry of Education and Culture of RS is fully authorized to develop and implement higher education policies in the entity. Thus, it is difficult to speak about a single higher education system in Bosnia and Herzegovina. It is probably more realistic to talk about twelve different higher education "systems" existing in the country, i.e. ten in the Federation of Bosnia and Herzegovina, one in the Republika Srpska and one in the Brčko District. Therefore, it is clear that the constitutive complexity of Bosnia and Herzegovina reflects the responsibilities regarding higher education." [3]

What is particularly noteworthy is that Bosnia and Herzegovina, as a lower-level state community, has 13 budgets for science and higher education, but at the same time it allocates less to this area than many countries in Eastern and Southeastern Europe. This is the fact that prevents planned long-term investments and funds in research. Which again reflects on the development of young staff in the natural and technical sciences. Well, in fact, they are completely turned to work and leave $\mathrm{BiH}$. This difficult situation is partly mitigated by the ERASMUS + programs, but their problem is that resources are scarce for Bosnia and Herzegovina and their realization mainly relates to the inclusion of individuals in other countries' programs.

Bosnian-Herzegovinian universities played a special role in this ethnicisation process. Since Bosnia remained the only republic without an "ethnic majority", the Muslim population became officially recognized as a "constitutive people" in the late 1960s. The formal equality of Croats, Muslims and Serbs was followed by the promotion of a newly-minted Muslim middle class, a practical task that was carried out mainly through the introduction of the so-called "national key" into cadre politics. This adaptation to the changes in the nationalities policy had effects on the universities, and produced in the $1970 \mathrm{~s}$ - two decades after the founding of the University of Sarajevo and the implementation of its academic personnel policy - a certain potential for conflict. When the party-political apparatus ordered the adaptation of "national subjects" curricula (historiography, literature, and linguistics) 92 and ordered equal rights for the Muslim academic cadres this lead to specific conflicts over the distribution of powers and responsibilities at the universities that more and more forced the academic elites to articulate their interests based on ethnic background [14].

The weight of restrictions is not the only problem of the academic community, which is largely attributed to the social misunderstanding of the position of these people, which arose in fact in the 1990s.

- A large number of restrictions arose from the period of the conflicts of war (1992-1995) that 
just created barriers between $\mathrm{BiH}$ and other states of the academic community;

- Public universities (especially the largest ones - Sarajevo, Mostar and Banja Luka Universities) were left by a large number of scientists, since the lost major equipment and space, in this respect, young professors generally gave up further studies or transferred to universities in neighboring countries;

- The constant outflows of students and junior associates have a very long tradition at almost all institutions (private and public. This trend has been around since the 1990s and has hampered the development of a standardized system and systems of excellence, as well as development of scientific careers in Bosnia and Herzegovina;

- Overall, a particular problem is the influence of politicians on governance and selection within institutions, which often lowers the criteria of future scholars and thus reduces their ability to respond to development demands and societies and academia.

The post-socialist period of university development in Bosnia and Herzegovina, in fact, did not exist. It was cut off by the war and aggression against Bosnia and Herzegovina in 1992-1995. and this significantly influenced the very process of transformation of these systems in the post-war period.

Socialist universities were completely devastated during the war and were left without a large number of teachers and associates. Their function during this period was almost negligible. Immediately after the signing of the Dayton Agreement, they were trained to continue their work and become involved in the reconstruction of the country. However, the only pattern they had was communist, managed by one party. In the postwar period, the Communist Party was replaced by national party organizations in certain parts of the country (based on the Dayton territorial structure). In addition, the introduction of a decentralized system of higher education governance is particularly advantageous to this process, as universities were administered by individual cantons and entities that did so under pre-war laws. In some cantons, the socialist laws were maintained until almost 2012. So the only governing system that the academic staff knew was the socialist system. In this case, it was precisely the application of decentralized rules established by Dayton Agreement with the socialist model of higher education governance. This was the foundation of the problem of transformation towards a modern European system.
However, the Bologna reform has created further confusion throughout the country.

Bosnia and Herzegovina started with Bologna process in 2003, even formally it was very turbulent, under great political and national pressures and concerns within the academic community as well as within political parties. These problems in particular got on the surface when it came to the adoption of a Statelevel Framework Law on Higher Education, and establishing a Higher Education Agency for quality assurance and accreditation. The adoption of the Framework Law was delayed by several years, as a result of anti-national political parties, who opposed to founding any kind of professional or administrative bodies for higher education on a state level (Bosnia and Herzegovina does not have a ministry of education at the state level, but deals with education at the international level through the Ministry of civil affairs). It was these anomalies that confused academic staff how to apply the rules of the Bologna process without having anyone to consult. This has led to the differences between the cantons and the entities today, and it creates distrust in diplomas awarded by higher education institutions, both in the labor market and in public.

Under the given socio-economic circumstances, certain socialist forms of politically "commercialising" scholarship have been revived, such as the inflationary production of scientific textbooks. The results can be bizarre, such as the fact that the current philosophy textbook of the Dean of the Faculty of Philosophy at one of Bosnia-Herzegovina's universities calls the classical Greek philosopher Socrates a "fascist". The market for books in Bosnia was heavily decimated by the war, and there is consequently little room for scholarly works. Thus those that are published are often bought only by public institutions (ministries, libraries, schools) and such purchase depends upon the partypolitical ideology of both the ministry official and the academic author. Another new form of political commercialization of higher education is the growing number of private colleges and universities that have recently been founded, above all in the Republika Srpska. While these commercial institutions were established with the help of political protection and capital secured by parliamentary Serbian parties, and are financed by fees that are too expensive for the average citizen, they do serve to guarantee for the new political and economic elites that their future family generations will hold onto their elite status. These purely educational institutions mainly offer diploma studies in management and economy and tie their ethno-nationalist content, marked by anti-civilian and anti-European ideas, to the biznis philosophy prevailing in Bosnian-Herzegovinian economy. Its ideas reflect the current economic situation, in which grey economy and the hunt for "fast money" dominate. Moreover, 
such an economy is one in which the lacking startup capital and investment are being compensated by ties to ruling state-party 106 structure and in which the absence of any legal security undermines the formal capitalist economic structure [14].

At the same time, the implementation of the Bologna reform was accompanied by the emergence of a number of private institutions, which created even greater problems in this fragmented system because the standards of establishment and operation are very different. However, the accreditation process, although formally set according to European principles, in its very performance has deviated from that realization. Especially when it comes to doctoral studies and university accreditation, which is ultimately left to lower levels. Because the Agency, established at the state level, made only a recommendation for accreditation, and the act of accreditation was given by the ministries of education at the canton or entity level. This has caused confusion and resistance of European entities to the accreditation process itself.

The very introduction of doctoral studies clearly showed the deficiency of the whole system, especially when it was seen that the doctoral study process itself cannot be carried out as in the rest of Europe, because of the lacking funds for doctoral research, nor can longterm funds be planned, because for the most part the lower levels mostly approve funds for salaries for employees and for the teaching process.

Higher education in Bosnia and Herzegovina is largely financed by public funds from the entity and cantonal budgets, the budgets of the Brcko district budgets, depending on the jurisdictions. Financing is still based on input parameters, such as number of employees and number of students. It means that this model of financing stimulates institutional dependence on state support, with no systemic mechanisms stimulating higher education institutions to find more efficient ways of spending public funds. Furthermore, the projected funds mostly cover higher education institutions operational costs. Funding for higher education in the Federation of $\mathrm{B} \& \mathrm{H}$ is under cantonal jurisdiction. It has the characteristics of a decentralized model. The Federation of $\mathrm{B} \& \mathrm{H}$ allocates funds to cantons according to an agreed formula, but the income allocation formula does not contain provisions specifically related to financing higher education, thus funds planned for financing higher education institutions are unequally divided between cantons. [3]

Due to the above mentioned, one has resorted to a very established process of "phishing" doctoral research, which is mainly related to the financial capacities of candidates or connecting with certain economic entities to solve much less important projects for the whole society. These issues are being solved more by the individual connections of professors with business organizations than by planning or system processes in cantons or entities. It is often the case that it is precisely because of these inability that young $\mathrm{PhD}$ students either choose to pursue a $\mathrm{PhD}$ in neighboring countries or go abroad.

Some strategic documents (in particular at the entity level) have so far paid little attention to the community's commitment to the advancement of researchers and young scientists, and even to their material standing. Therefore, it became clear that the decentralized model of education in Bologna conditions made the position of that category of researchers even more difficult:

- Economically,

- Politically,

- Socially,

- Internationally.

The general shortcomings of this Bologna model did not arise at once, it was clear from the beginning that institutions with these assets and status would not be able to meet the standards in Europe (ESG), which was then reflected by lowering the criteria and making political decisions on the accreditation of individual institutions. In the end, this resulted in the Agency's unsuccessful attempts to become a full member of ENQA and EQAR, and with the harsh critical tone expressed by these agencies towards Bosnian bodies membership applications.

In this whole situation, there was only a formal emphasis on the standards and the fact that some institutions are untouchable and the fact that they earned that status under political influence.

"By analyzing higher education at the current higher education institutions, especially state, but not less so, private ones, we can conclude that this is an unfinished concept, which essentially represents the harmonization of the influence of society with the capabilities of the system. The neoliberal concept of higher education has greatly altered the logic of the teaching process itself, which has increasingly diverted into so-called banking concept of higher education, with unclear implications for the labor market. In fact, the current organization of the system was based on the principle of working without supervision and without responsibility." [12]

This raises the special question of the real attitude and position of scientists and professors in Bosnia and Herzegovina, and the persistent attitude of society towards higher education institutions. Immutability becomes the main logic of the whole system. This country is, in fact, an extreme example of what Marek Kwiek writes about: 
First of all, the Central European Academic Staff, as well as the politicians and legislators responsible for higher education reform, should not continue to believe in the region's popularity and the associated three myths:

- The myth that post-socialist universities, because of their history, are exceptional in Europe and should therefore be preserved in their unaltered or minimally changing form (especially because they are indebted to their needs, largely encroaching on the concerns of society and the economy);

- The myth that post-socialist universities as public-sector institutions are radically different from all other public-sector institutions and immune to the impact of global and European public-sector reforms;

- The myth that knowledge production can be clearly seen only in the international context of reformed higher education systems (in this sense only in financial methods), even at the present low public spending on research and development.

The belief in these myths, to varying degrees by scientific staff, politicians and legislators, has paralyzed the production of knowledge in the region for over twenty years. Any serious attempt at systemic reforms must confront them. [9]

\section{INDIVIDUAL SCIENTISTS POSITION IN BOSNIA AND HERZEGOVINA}

The weight of the position of scholars and professors in Bosnia and Herzegovina is in every aspect related to the research process itself, and not only to the amount of revenue generated by teachers. Teachers' salaries in some public universities (Sarajevo Canton) are quite high (at times higher than in some EU countries), but the resources needed for research and teaching are very limited, almost unable to cover serious research or to carry out a quality process classes. In addition, the process of allocating money is conditioned primarily by political criteria, but also by the positions of certain professors at universities. It complicates the whole situation even more. And it begs the question of the silent conflict of generations.

In Bosnia and Herzegovina, this gap between the generations at universities is even more pronounced than in other Eastern European countries. And in that sense, it feels like some older generations of teachers tend to decelerate the modernization process. Focusing on this topic, Marek Kwiek, and describing relations in Poland, has largely diagnosed the situation in Bosnia and Herzegovina as well:
"There is a new method of distribution for academic work between young researchers (under 40 in our example) and their older colleagues: most new research programs at the National Science Center are directed at young scientists, and there is a growing feeling that new researchers are subjected to more demanding rules of science career developments (heightened pressure for publishing in top international journals) are unfair. They affect them primarily or most of the time and they do not affect the functioning of senior staff. Our research has uncovered the general situation in which they function in Poland today with two types of researchers. The first type mainly involves senior staff members, mostly unable to achieve and maintain productivity, internationalization (as part of research and publication channels) and international mobility required by new laws (and increasingly in new employment procedures and the transition to new ones). At the same time, older generations are characterized by a lack of understanding for new, competitive mechanisms for funding scientific research and publishing results, understanding for the broader idea that science is an extremely competitive endeavor. This idea has been virtually unknown in Poland in recent decades, and certainly has not been the basis of contemplation about academic work. Segmentation among staff that are the direct result of more and less competitive scientific advances were almost nonexistent, as they have not affected serious differences in prestige and access to resources (resources for research, infrastructure and involvement of young people). [6]"

So, this is already a clear internal conflict within institutions that is almost unknown to Western countries. The basic question is, in Bosnia and Herzegovina, is anyone systematically engaged in producing knowledge and incorporating knowledge into social flows? The truth is that universities are, in fact, left to themselves and depend to a large extent on the staff who lead the schooling and scientific processes. As in all countries of Central and Eastern Europe and Bosnia and Herzegovina in the 1990s, the focus of higher education institutions was concentrated on teaching. But unlike most of the countries already mentioned, this trend in Bosnia and Herzegovina continues to this day. Lack of money for scientific work, poorly conceived doctoral studies, lack of criteria and serious accreditation for the scientific field have influenced almost all institutions to mainly focus on teaching. In this context, though, there are serious differences that are clearly seen in the labor market, both between public and private universities. The quality of knowledge that new generations of college graduates gain is much lower than the one their predecessors from the socialist period had.

At the same time, the shift of generations within higher education institutions is accompanied by a clear decline in the standard related to the acquirement of a 
profession and the very motivation for research and scientific work. Therefore, many young researchers, in addition to their work at universities, are forced to pursue additional jobs (many of which have nothing to do with higher education) to cover their basic costs. Because the state has largely shifted the whole process of advancing young cadres to them without any interest in how the quality of their knowledge and skills will be reflected.

Because at the entity level, these funds are very minuscule. Precisely as Marek Kwiek describes it:

The consequences of such institutional weaknesses in the production of knowledge at universities are multifaceted: first of all, in the absence of powerful, socially accepted narratives linking the university's past, present and future, translating reforms into governance and funding, so that the last two decades have been much less important than should be. Cosmetic reforms are often introduced. Public interest of universities was focused on growing their educational opportunities and increasing enrollment rates, and they were also fascinated by the policy of enrolling an increasing number of students to compete for the social legitimacy (usually without success or with only partial success) of the private sector in the region.

The identity crisis of the academic profession was caused, among other things, by the lack of thorough institutional research and the low level of salaries of academic staff, leading to ten unproductive years, with superficial reforms lacking ambition of a structural nature and loss in the sphere of interest of public universities as an institution of knowledge production. The consequence of these processes, on the other hand, was the gradual loss of interest in the mission of legislators for university research (in addition to the educational mission), and the third task of the university (in different versions) was to produce knowledge, which was analyzed in this text, therefore, the production of scientific knowledge - no production of graduates, better or for worse prepared for the challenges of evolving job markets. [5]

Bosnia and Herzegovina is a typical example of this behavior. Young scientists have the most difficult position in public universities because they are under a great deal of pressure from political factors that force them to do only those jobs that are "politically interesting and needed by governing structures". These young scientists are under a constant system of threats and a ban that prevents them from doing their research freely. The prohibitions imposed on them are constantly visible through various regulations restricting cooperation between public and private universities, cooperation between universities from different entities or cantons.

\section{DIVISIONS AND DEVIATIONS OF ACADEMIA IN BOSNIA AND HERZEGOVINA}

Of course, most scientists and professors left Bosnia and Herzegovina during the 1992-1995 war years. After the Dayton Peace Agreement was signed, few returned to the country. Most of them remained in neighboring countries. At that time, individual colleges were split between the two entities or sent to new locations. That is why the issue of academic freedom in Bosnia and Herzegovina is very rarely used or most often not mentioned at all. Although there are many examples of violations of academic rights at many universities.

What characterizes it is the violation of academic rights in many public and private universities.

"To our question to Professor Dubravko Lovrenovic from Sarajevo University, what is the true state of the universities in this country, we have received an answer - primitive and banal: "Since the university has become a place for perfect irresponsibility — you cannot come to work, you do not have to come. you can teach, you don't have to teach, university become a safe haven for failed politicians, no university can ever fail because their departments are waiting for them. Universities have become the posts of rectors against whom multiple applications have been filed, inspection and criminal. These have become the places where the dean of the faculty signs his election as rector of that same university. So this is the state of Hiroshima's spiritual landscape, "Lovrenovic estimates." [15]

Political pressures have intensified since the war, especially since 2014, when the crisis began to erode the academic community, but the outflow of young people from these areas has accelerated. What distinguishes the reality of Bosnia and Herzegovina from the European reality is the attitude of the environment towards the problems of the academic community.

The long-standing political wanderings of Bosnia and Herzegovina between East and West, a transition that grows into a lasting state, because in fact transition only exists in our heads, are an excuse for not accepting change. Economy has no boundaries, religion has no boundaries, but local politics unfortunately has boundaries. Such attitudes have produced a strong partocracy where one or two political parties hold everything in their hands. This is why ministers of education often appear as people who don't even have the academic title of Doctor of Science, so it happens that in some Cantonal Ministries of Education there is no single Doctor of Science employed. There are higher education institutions, they exist, but there is no one to advise them. That is why there is someone to control, threaten and blackmail them. Anything can be found, except knowledge. Are we going back to the policestate regimes, or perhaps better, have we ever left 
them? Of course corruption and manipulation will flourish in such environments. Corruption as such is produced by the state itself, in our case the cantons, since any strategy for modernization requires planned and permanent financing. There are demands for greater accountability and efficiency, as well as quality concerns. Because the cantons are impoverished, without money, money will be taken from students for universities to survive.[9]

The academic community of Bosnia and Herzegovina in the environment in which it is located is completely left to a range of circumstances that do not benefit it. And this is evident from every text that was published in this country lately. The above mentioned details can be classified into several parts:

- The $\mathrm{BiH}$ academic community is nationally divided and restricted to create joint projects and interventions;

- Political pressures are of such a nature that they simply prevent the development of a unified strategy that would launch both the higher education system and large scientific research;

- Economic dependence on political actors has marginalized the status and opportunities of academics;

- This led to the complete vulgarization of the teaching professions which made young people unwilling to take up this vocation and leave the country.

The disintegration of the former Yugoslavia led to the homogenization of society, the strengthening of national discourse and religious intolerance. Mental circuits of exclusivity have been made. The relapses of totalitarianism are deeply rooted in academia. Human rights are not respected. Dialogue does not exist, we do not listen and we do not respect it. We do not talk to non-like-minded people, we do not accept other people's views, there is no empathy for the environment, and worst of all - we are not dealing with ourselves either, we have lost a person in ourselves. But we are not aware of that either. Every day we hear about the benevolence of our benefactors and talk about their works, their lives, how difficult it is for them and how they struggle to get us out of the crisis. It is this manipulative power of the media that is solely for the purpose of politics, all for the sole purpose of freeing the common man of every opinion, making his life "simpler". Thus came what From calls conformism. He describes it as a mechanism of escape from exploration and finding of one's own personality and clashes with powerful individuals and institutions, which will defend the existing situation and try to prevent the release of personality by all forces. A free man is a dangerous man. [9]
The issue of national discourse in the academic sphere is so large that it is difficult to understand in Europe how much fear this is within higher education institutions.

In researching the position of academia in Bosnia and Herzegovina, we came to the conclusion that the constitutional division of education (highly decentralized education management system) is used to lose uniform standards in higher education and science and especially in the systematic derogation of academic work (from autonomy to integrity), as well as fragmentation and social marginalization of scientific research. It is possible to see this in many respects, but especially in the benefits of the non-investing in science and innovation used by government agencies in the last 20 years, which has influenced researchers position to their social environment, in a way that their work is marginalized and especially affects projects that are interconnected with social development.

By territorial division (entities and cantons), the academic community in Bosnia and Herzegovina exists in isolated islands, which are on the brink of extinction, and are highly dependent on local administrators and their views on the development of education. Therefore, by operating in a system of insecurity, they turn into groups of like-minded people, who are aware of their position and opportunities, negatively treat everyone who brings new ideas to the academic space of Bosnia and Herzegovina. In addition, the impossibility of implementing larger projects influenced the creation of the idea of feigning the academic community in those parts that refer to meeting international standards. All this has conditioned the great departure of young talented academic associates and teachers, and the taking over of managerial jobs by individuals who do not have any kind of academic career, but possess political suitability. This pattern has spread throughout the country, but one academic mosaic of small, inefficient academic environments has been obtained that fulfills only teaching activities to the extent required by law. Real academic life died out in those environments. Following these phenomena, we came across the problem of atypical behavior of academics in these isolated islands, which largely coincides with the behavior of Internet communities, so using that classification we applied them to isolated academic spaces. Effectively, we were able to use three significant terms that analyze C. Thi Nguyen:

- Cognitive echo chambers,

- Cognitive Islands,

- An epistemic bubble.

The most important segment we are dealing with here is the transformation of academic communities into cognitive echo chambers. Cognitive echo chambers 
are based on confirmed bias, and refer to the reception of information that confirms already existing beliefs, and ignores information and facts that are contrary to these views. These chambers are based on the cognitive capacity that community members (in this case academic) share views, regardless of the development of new technologies, which are hermetically sealed for any form of dissent. Echo chambers as (academic) entities achieve their dominance usually by subjectivization and linking individual opinions with community interests. The emergence of such dominant opinions has two basic paths: The first — when a certain network of individuals with a similar worldview is formed and operates [14]

Others - as a result of accepting the position of an influential individual, which was accepted by the users themselves in order to preserve privileges.

Cognitive islands - Cognitive islands are those areas of knowledge that require expertise to assess other experts. Cognitive islands and places are where we have the least resources to assess experts and scientists coming from other fields, leading to declarative recognition and usually rejection of any sort of help. Cognitive islands are professional spaces that usually do not have the standards that would be available in the assessment of expertise to those who are not experts themselves.

In order to understand the nature of cognitive islands, let's start with a brief analysis of what isn't a cognitive island - what's on the cognitive mainland, so to speak. A domain is on the cognitive mainland if expertise is unnecessary to decide which experts to trust. On the cognitive mainland, a novice can successfully identify a genuine expert from among the posers. They can also assess an expert's degree of expertise, especially in those situations where different legitimate experts disagree. [7]

Secondly, they are separated from other scientific spaces by a false presentation of the situation, which usually aims to get experts from abroad. Typically, standards are formed here for party-political ties that usually do not have a common character with neighboring areas.

Epistemic bubbles are problematic academic structures that confuse members of the academic community because they are based on omitting facts that relate to the evaluation process (individual, project, book). Both reinforce the ideological separation of the cognitive islands from the wider community and form the basis for closure.

The recent conversation, however, has blurred two distinct, but interrelated, social epistemic phenomena, which I will call epistemic bubbles and echo chambers. Both are problematic social structures that lead their members astray. Both reinforce ideological separation.
But they are different in their origins, mechanisms for operation, and avenues for treatment. Both are structures of exclusion - but epistemic bubbles exclude through omission, while echo chambers exclude by manipulating trust and credence. However, the modern conversation often fails to distinguish between them. Loosely, an epistemic bubble is a social epistemic structure in which some relevant voices have been excluded through omission. Epistemic bubbles can form with no ill intent, through ordinary processes of social selection and community formation. We seek to stay in touch with our friends, who also tend to have similar political views. But when we also use those same social networks as sources of news, then we impose on ourselves a narrowed and self-reinforcing epistemic filter, which leaves out contrary views and illegitimately inflates our epistemic self-confidence. [8]

Epistemic bubbles can also arise from ignorance of the course of scientific research, methodology, standards, etc. But they are most often abused with the aim of rejecting opinions or attitudes from others.

In the academic islands of Bosnia and Herzegovina, all three of these forms have grown tremendously in academic spaces over the last 20 years. They have led to the abandonment of a large number of young researchers, but also to the introduction into the academic world of individuals who do not even have the basic foundations to be in it. And that is the key to the disappearance and all forms of work of the academic community of Bosnia and Herzegovina. Today, because of these indicators, it exists only on paper or as an educational segment of society without international recognition.

\section{CONCLUSION}

It is quite difficult to relate several important things to understand what Bosnia and Herzegovina lacks:

- Serious strategic documents regarding higher education and science;

- Corruption and political pressure within the institutions;

- Absence of any form of protection of academic freedom and university autonomy;

- Workplace insecurity in higher education;

- Absence of public solidarity with university teachers;

- The lack of interest of the state authorities to enter higher education and science at all.

Finally, it should be emphasized that scientists and professors in Bosnia and Herzegovina have been in a very difficult position for a long time and in a great depression that their work and their commitment to 
scientific work in general is under the threat of political and tycoon lobbies. Today, they are powerless to do anything to improve their position.

\section{References}

[1] Elizabeth Dubois \& Grant Blank The echo chamber is overstated: the moderating effect of political interest and diverse media Information, communication \& society, Taylor \& Francis Published online: 29 Jan 2018

\section{https://doi.org/10.1080/1369118X.2018.1428656}

[2] Eric Gilbert, Tony Bergstrom and Karrie Karahalios, Blogs are Echo Chambers: Blogs are Echo Chambers, Published in: 2009 42nd Hawaii International Conference on System Sciences, Big Island, HI, USA, 2009. DOI: 10.1109 / HICSS.2009.91

[3] Jovanović V., Cekic Markovic, J, Jokić T. Stanković D. (2016): Social Dimension of Studying in Bosnia and Herzegovina Eurostudent $\mathrm{v}$ Report for the Federation of Bosnia and Herzegovina Eurostudent. eu Centre for Education Policy, Belgrade. ISBN 978-86-7522-052-7.

[4] Kiran Garimella, Gianmarco De Francisci Morales, Aristides Gionis, Michael Mathioudakis. Political Discourse on Social Media: Echo Chambers, Gatekeepers, and the Price of Bipartisanship, Publication: WWW'18: Proceedings of the 2018 World Wide Web Conference. April 2018. Pages 913-922. https://doi.org/10.1145/3178876.3186139

[5] Kwiek Marek: Universites in times of changing institutions and academic staff in the conditions of growing competition, Warsaw, 1, 2015., Publisher: PWN Publishing house (Uniwersytet $\mathrm{w}$ dobie przemian instytucje i kadra akademicka w warunkach rosnńcej konkurencji Warszawa, 1, 2015 Wydawca: Wydawnictwo Naukowe PWN) http://cpp.home.amu.edu.pl/wpcontent/uploads/2016/09/Kwiek_2015_PWN_Spis_tesci_wpro wadzenie.pdf

[6] Kwiek Marek Universities, knowledge, production and economic competitiveness in Central Europe, science and higher education, No 1-2/43-44/2014, Warsaw, 2014. (Uniwersytety, Produkcja Wiedzy i Konkurencyjność Gospodarcza w Europie Środkowej, Nauka I Szkolnictwo Wyższe, Nr 1-2/43-44/2014 Warszawa 2014) file://C:/Users/Dell/Downloads/Kwiek_Produkcja_wiedzy_201 4.pdf.

[7] Nguyen, C.T. Cognitive Islands and Runaway Echo Chambers: Problems for Epistemic Dependence on Experts. Synthese (2018). Published: Springer. 22 January 2018. https://doi.org/10.1007/s11229-018-1692-0

[8] Nguyen C. Thi: Echo Chambers and Epistemic Bubbles, Published online by Cambridge University Press: Episteme, Cambridge, 13. September 2018, DOI. https://doi.org/10.1017/epi.2018.32

[9] Šećibović, Marijana Truth and lies about academic community of Bosnia and Herzegovina, Science-SpiritualityResponsibility- Proceedings of Scientific professional conference, held on September 27, 2014. University of Herzegovina, Faculty of social sciences dr. Milenko Brkić, September 27, 2014. Međugorje, ISBN 978-9926-412-00-5 (Istina i laži o akademskoj zajednici Bosne i Hercegovine, Znanost-Duhovnost-Odgovornost Zbornik Radova Znanstvenostručnog Skupa Održanoga 27. Rujna 2014. Sveučilište Hercegovina Fakultet Društvenih Znanosti Dr. Milenka Brkića, 27. 09. 2014. Medjugorje, ISBN: 978-9926-412-00-5.)

https://bib.irb.hr/datoteka/922615.
[10] Šećibović Marijana: Apories of Intercultural Communication, Media, Culture and Public Relations. Vol.6 No.2, 2015. Zagreb, Hamster ID: 149019 URI.

https://hrcak.srce.hr/149019 https://doi.org/10.32914/mcpr

[11] Šećibović R, Šećibović M: Europeanization in education and Ideological Manipulations Proceedings from the International Scientific Conference Identity In The Era Of Globalization And Europeanization 3-4 November 2011, Skopje Republic of Macedonia.

https://www.ceeol.com/search/article-detail?id=217594

[12] Šećibović Refik.: Fortress of Boredom, HERAedu, Belgrade, October 2016. ISBN:978-86-7956-103-9 Google scholar (Tvrđava dosade, HERAedu, Beograd, oktobar, 2016 ISBN:978-86-7956-103-9 Google scholar).

[13] Šecibović Refik. Fortress of the hunters in the murky: Essay about political management of education, Čigoja Publishing House, 2009, Belgrade, ISBN 8675586590 (Tvrđava lovaca u mutnom: Esej o političkom upravljanju obrazovanjem Čigoja Štampa, 2009,Beograd. ISBN 8675586590.)

[14] Weber, Bodo: The Crisis Of The Universities In Bosnia And Herzegovina And The Prospects Of Junior Scholars, Fridrich Ebert Stiftung, Bosnia and Herzegovina, 2007 Sarajevo. http://library.fes.de/pdf-files/bueros/sarajevo/09245.pdf

[15] https://www.slobodnaevropa.org/a/sveucili\%C5\%A1tima-u-bihupravljaju-politike/25358513.html - Universities in Bosnia and Herzegovina are managed by politics, Radio Liberty, Free Europe article

[16] https://www.6yka.com/novosti/filozof-zeljko-radinkovic-zabuku-akademska-sloboda-je-prisutna-samo-u-onoj-mjeri-ukojoj-je-drzava-tolerise, Željko Radinković for BUKA magazine, Academic liberty is present only in the measure that politics allows it to be present

[17] https://ekran.ba/?p=2894 